\title{
Influence of rhizobium inoculation combined with azotobacter chrococcum and bacillus megaterium var phosphaticum on growth, nodulation, yield and quality of two snap been (phasealus vulgaris $l_{\text {.) }}$ cultivars.
}

\author{
Gharib, A.A.; M.M. Shahein and A.A. Ragab* \\ Cairo University, Faculty of Agriculture, Vegetable Crops Department. \\ *Central Lab. of Organic Agriculture, ARC, Giza, Egypt.
}

\begin{abstract}
The present investigation was carried out during the two successive summer seasons of 2007 and 2008 at the Experimental Station, Faculty of Agriculture, Cairo University, Giza, to study the effect of inoculation with Rhizobium leguminoarum bv. phaseoli (ARC 301) (Rh), Azotobacter chroococcum (AZ1) and Bacillus megaterium var phosphaticium (BM3) on nodulation , $\mathrm{N}_{2}$-fixation, population of rhizosphere microorganism (RMO), NPKContent, yield and pod quality of two snap been (Phaseolus vulgaris L.) cultivars, namely Bronco and Paulista under $25 \%$ of the recommended dose of NPK chemical fertilizers. Results indicated that inoculation with biofertilizers mixture had a significant effect on snap been growth parameters, nodulation and $\mathrm{N}_{2}$-fixation. The highest values were recorded with $\mathrm{Rh}+\mathrm{AZ1}+\mathrm{BM} 3$ in presence of $25 \%$ the recommended dose of NPK fertilizers. Paulista cv. surpassed cv. Bronco in plant height, plant fresh and dry weights, both number of branches and pods/plant as well as leaf chlorophyll content, whearas the reverse was true concerning the plant yield, early and total green pod yield and dry seed yield per feddan, pod weight and diameter as well as pods dry matter, carbohydrates and fibres. Rhizobium $(\mathrm{Rh})+$ Bacillus megaterium (BM3) with $25 \%$ the recommended dose of NPK significantly increased all traits of vegetative growth, yield and its components and pod characteristics in comparison with the control treatment (uninoculated $+100 \% \mathrm{NPK}$ ). The best interaction treatment regarding plant growth and chlorophyll leaf content was cv. Paulista with Rh + BM3 $+25 \%$ NPK. Meanwhile, cv. Bronco with the same treatment was the best regarding yield and its components as well as pod characteristics.
\end{abstract}

Key words: bacterial inoculation, Snapbean, biofertilizer

\section{Introduction}

Snap bean (Phaseolus vulgaris L.) is one of the most important vegetable crops grown in Egypt for local consumption and exportation. Also, it is widely used as a source of protein and for its high nutritive value for human nutrition.

It is well known that common beans are environmently sensitive and had low levels of nodulation and $\mathrm{N}_{2}$-fixation because these processes are very sensitive to many factors related to environmental conditions and cultural practices (Semu et al., 1982, Moawad et al., 1998; Ravindar and Chandra, 2008). Thus, the literature describing the effectiveness of Rhizobium inoculation in increasing vegetative growth, yield and nitrogen content of common bean plants are contradictory, partially because different bean cultivars (Daba and Haile, 2002) environmental and soil conditions (Hernandez - Armenta et al., 1989; Carvalho et al., 1998) and Rhizobium strains (Lalande et al., 1990; Sanoria and Yadav, 1993). For example, inoculation of common bean plants with Rhizobium was not effective, when it was conducted in irrigated soil (Carvalho et al., 1998) or when the soil temperature was $38^{\circ} \mathrm{C}$, or higher, immediately after inoculation (Hernandez - Armenta et al., 1989) or when the application of nitrogen was increased (Datt, et al., 2006). On the other hand, inoculation of Phaseolus vulgaris with Rhizobium increased plant hight, pods per plant, fresh weight per plant, seed yield and NPK uptake (Rana et al., 2006).

The major aspect which may increase the yield of legumes is inoculation with free or associated nitrogen fixing bacteria, which can fix nitrogen by themselves (Chripeels and Sadava, 1994), improve plant growth, through producing fungistatic substance (Gupta et al., 1995) or through improving symbiotic parameter of legume Rhizobium association (Singh and Subba Rao, 1979).

Moreover, it well be useful to use microelements (such as boron and molybdenum) or vitamin $\mathrm{B}_{12}$ as well as arbuscular mycorrhizal fungi (AMF) along with Rhizobium phaseoli inoculation to improve growth, yield and nutrient uptake of bean plants (Ismail, 2002; Aryal et al., 2003).

The aim of this investigation was to study the effect of rhizobial inoculation plus (Azotobacter chroococcum and Bacillus megaterium) on nodulation, plant growth, yield and its components as well as pods quality of shop bean (cvs. Bronco and Paulista) grown in clay-loam soil.

\section{Materials and Methods}

This study was carried out during the two successive summer seasons of 2007 and 2008 at the Experimental Station, Faculty of Agriculture, Cairo University, Giza, to study the response of two snap bean (Phasceolus 
vulgaris, L.) cultivars, namely Bronco and paulista, to inoculation with Rhizobium leguminosarum biovar phaseoli "ARC301", Azotobacter chroococum "AZ1" and Bacillus megaterium var. phosphatrcum "BM3".
The physical and chemical properties of the experimental soil (Table 1) were determined according to the method of Jakson (1958).

Table 1: Physicochemical properties of the experimental soil.

\begin{tabular}{|c|c|c|c|c|c|c|}
\hline \multicolumn{3}{|c|}{ Mechanical analysis } & \multirow{2}{*}{$\begin{array}{l}\text { Textural } \\
\text { class }\end{array}$} & \multirow{2}{*}{$\begin{array}{c}\mathrm{CaCO}_{3} \\
\%\end{array}$} & \multirow{2}{*}{$\begin{array}{c}E C \\
\mathrm{dS} / \mathrm{m}\end{array}$} & \multirow{2}{*}{$\begin{array}{c}\text { PH } \\
1: 2.5\end{array}$} \\
\hline Clay\% & Silt\% & Sand $\%$ & & & & \\
\hline 51.20 & 38.58 & 10.22 & Clay-loam & 3.5 & 4.1 & 7.6 \\
\hline \multicolumn{3}{|c|}{ Macroelements (ppm) } & \multicolumn{4}{|c|}{ Microelements (ppm) } \\
\hline $\mathrm{N}$ & $\mathrm{P}$ & K & $\mathrm{Fe}$ & $\mathrm{Zn}$ & $\mathrm{Mn}$ & $\mathrm{Cu}$ \\
\hline 95 & 34 & 718 & 4.5 & 3 & 15 & 2.8 \\
\hline \multicolumn{3}{|c|}{ Soluble anions (meg/L) } & \multicolumn{4}{|c|}{ Soluble cations (meg/L) } \\
\hline $\mathrm{HCO}_{3}^{-}$ & $\mathrm{Cl}^{-}$ & So $^{-2}$ & $\mathrm{Ca}^{+2}$ & $\mathrm{Mg}^{+2}$ & $\mathrm{Na}^{+}$ & $\mathrm{K}^{+}$ \\
\hline 1.5 & 6 & 29.1 & 18.9 & 6.1 & 9.9 & 1.5 \\
\hline
\end{tabular}

Bean seeds were sown on $5^{\text {th }}$ March in the two seasons. Before sowing, seeds were coated with a thin film of Rhizobium leguminosarum biovar phaseoli "ARC301" and the other two bacterial stains separately or in combination using gums Arabic $40 \%$. The experiment was arranged in a split plot design with three replications, where the two cultivars were put in the main plots, and the six biofertilizers treatments were randomly distributed in the sub main plots. The experiment included 12 treatments representing the various combinations of bean cultivars, bacterial strains and NPK recommended fertilizer level.

The bacterial strains Rhizobium leguminosarum bvr. phaseoeli (ARC 301), Azotobacter chroococcum (AZ1) and Bacillus megaterium var. phosphatecium (BM3) were provided by central Lab. of organic agriculture, ARC, Giza Egypt.. Three different broth media were used: yeast extract mannitol for Rhizobium (Vincent, 1970), modified ashby for Azotobacter (Hegazy and Neimela, 1976) and Bunt and Rovira (1955) for Bacillus megaterium (Bunt and Rovira, 1955). Each bacterium was grown on the appropriate medium and incubated at $28^{\circ} \mathrm{C}$ for 3 days until early log phase. Vermiculite supplemented with $10 \%$ Irish peat was packed on polyethylene bags as a carrier (300 g per /bag), then sealed and sterilized by gamma irradiation $\left(5.0 \times 10^{8} \mathrm{rads}\right)$. Bacterial culture was injected into steilized vermiculite to satisfy $60 \%$ of the maximal water holding capacity, then, the inculation rate were used as $300 \mathrm{gm}$ inocula / feddan for each microorganism (50\% for seed inoculation and $50 \%$ at 15 day after planting).

Microbial inoculation was done twice, the first was before sowing as seed coating and the other was add after 15 day from sowing. Also, total counts of bacteria, actinomycetes and fungi were estimated in rhizosphere soil samples of the two seasons according to Wollum (1982). Nitrogenase activity was measured as acetylene reduction assay (ARA) according to the method described by Hardy et al. (1973).

The six combination treatments were as follows:
1. Untreated plants.

2. Plants received the recommended NPK levels without biofertilizer.

3. Plants inoculated with Rhizobium leguminosarum biovar phaseoli "ARC301" $(\mathrm{Rh})+25 \%(\mathrm{NRL})$.

4. Plants inoculated with Azotobacter chroococum "AZ1"+ $25 \%$ (NPKRL).

5. Plants inoculated with $\mathrm{Rh}+$ Bacillus megaterium "BM3" + $25 \%$ (NPKRL).

6. Plants inoculated with $\mathrm{Rh}+\mathrm{AZ1}+\mathrm{BM} 3+$ $25 \%$ (NPKRL).

The last four treatments received only $25 \%$ of the recommended NPK dose while the second treatments received $100 \%$ of recommended NPK dose and the first treatment did not received any bio or normal fertilizers considered as controls. The plot area was $13 \mathrm{~m}^{2}$, consisting of 5 lines (4m length and $65 \mathrm{~cm}$ apart). One line was devoted for vegetative growth parameters samples, and the other two lines were used for green pod yield, while the remainder two lines were used for dry seed yield determination. One line was left between every two plots as a guard line. The inoculated or un inoculated seeds were sown in hills at $5 \mathrm{~cm}$ apart. Three to five seeds were sown in each hill. Ten days after sowing, plants were thinned to two plants per hill.

Five plants from each experimental plot were taken randomly after 60 days from sowing to determine plant length, fresh and dry weights as well as number of branches/plant, number of nodules and their dry weights. The chlorophyll reading in leaves was recorded (at the beginning of flowering) by A Minolta SPDAD chlorophyll-meter, model SPAD 502 (Yadava, 1986).

Pods were harvested at green maturity stage every. 7 day, then counted and weighted. The following characters were recorded.:

1. Weight and number of green pods per plant were measured on ten plants taken randomly from each plot during all harvesting times.

2. Weight of green pods for the first and second harvests taken from each plot was recorded, then 
the average yield of green pods/fed. was calculated and considered as early yield per feddan.

3. Weight of green pods taken during all harvestings of green pod yield/plot. Was recorded then calculated as total yield per feddan.

4. At pod maturity stage, dry pods of the two lines that devoted for dry yield from each plot were collected after about 100 days from sowing, then dry bean seeds were separated and weighed to determine the dry yield per feddan.

5. Ten green pods were taken randomly (from the third harvest) from each experimental plot for measuring the average pod weight $(\mathrm{g})$, pod length (cm) and pod diameter ( $\mathrm{mm})$.

Hundred gram of fresh leaves and pods (obtained from three plants) taken randomly from each experimental plot at the thrid harvest, were ovendried at $70^{\circ} \mathrm{C}$ till constant weight, the dried samples were taken to measure N,P and $\mathrm{K}$ in leaves and pods as well as pod dry matter, protein, total carbohydrates and crude fibers according to (Huphries 1956; Taussky and Shorr 1952; Brown and Lilliland 1964; Stewart, 1989 and A.O.A.C ( 1980). Statistical analysis of the obtained data was conducted through the analysis of variance according to Snedecor and Cochran (1980). For comparison between means, L.S.D. at 0.05 was calculated.

\section{Results and Discussion}

\section{Vegetative growth:}

As shown in Table (2) Paulista cv. exceeded cv. Bronco in plant height, fresh and dry weight, number of branches per plant as well as chlorophyll leaf reading in both seasons. There were significant differences among the bacterial inocula on all vegetative growth traits and chlorophyll reading especially in the two seasons except the number of branches per plant in the second one. Inoculation with Rhizobium leguminoarum bv. phasaoli $(\mathrm{Rh})+$ B. megaterium (BM3)in presence of $25 \%$ recommended NPK had the highest values for all triats of vegetative growth followed by $\mathrm{Rh}+\mathrm{AZ} 1+\mathrm{BM} 3+25 \%$ NPK. The interaction between microbial inoculation and cultivars was significant on plant height, plant fresh weight as well as leaf chlorophyll content. On the other hand, the interaction was not significant on plant dry weight and number of branches per plant especially in the second season. Meanwhile, treated with $\mathrm{Rh}+\mathrm{BM} 3+$ $25 \%$ NPK exhibited the highest values of all studied traits for both cultivars, while uninoculated plants showed the lowest ones. The obtained results are in agreement with those reported by Singer et al.,
(1996) who concluded that applying 50 or $75 \%$ of recommended NPK doses and inoculation with Rhizobium. Sp. and Azosperillum spp. or Rhizobium spp. with soil yeast (Cand. sp) to snap bean plants resulted in vigorous plant growth. Similarly, Abd ElFattah and Arisha (2000) indicated that, the stimulative effect of Rhizobium inoculation on morphological characters of bean plants might be due to that the treated plants with Rhizobium fixed high amounts of nitrogen which in turn increased plant growth parameters.

\section{Nodulation and $\mathbf{N}_{\mathbf{2}}$-fixaction:}

Data presented in Table (3) indicated that Rhizobium inoculum significantly increased numbers and dry weight of nodules and nitrogen fixation activity as compared to uninoculated treatments. Irrespective of cultivar, $\mathrm{co}^{-}$inoculation with Rhizobium and Azotobacter or Bacillus megaterium var phosphaticum or together, did enhance the nodulation and $\mathrm{N}_{2}$ - fixation of snap bean plants. In general, data recorded in the second season was higher than those obtained in the first one. The same trend was obtained for cvs. Paulista and. Bronco. These results are in harmony with those obtained by Abdel fattah and Arisha (2000) and Ravindar and Chandra (2008), who reported that, mixed inoculation with Rhizobium and $\mathrm{N}_{2}$ fixing bacteria or phosphate dissolving bacteria increased nodulation and $\mathrm{N}_{2}$ fixation of some leguminous plants.

\section{Microbial status:}

Data in Table (4) showed that fertilizing snapbean plants with recommended dose of NPK had a negative effect on rhizosphere microorganism (RMO). This treatment scored the lowest number of total bacteria, fungi and actinomycetes compared to the inoculated treatments. Also, in both seasons, inoculation with Rhizobium alone or mixed with Azotobacter or Bacillis megaterium var phosphaticum gave the higher number of total bacteria, fungi and actinomycetes compared to uninoculated one. Irrespective of cultivar the triple inocula treatment gave the higher number of RMO compared to others. Similar results were obtained in both seasons for both cultivars. These results are in agreement with those obtaind by Ragab, Mona et al (2006) and Ashrafuzzaman et al (2009). They reported that inoculation with the plant growth promoting rhizobacteria (Azotobcter, Bacillus megaterium, Rhizobium ) had simulative effect on the population of rhizosphere microorganism (RMO) and increased their numbers by more than $50 \%$ at the end of the experiment . 
Table 2: Effect of some bacterial strains on vegetative growth and chlorophyll content of snap bean cultivars during 2007 and 2008 seasons.

\begin{tabular}{|c|c|c|c|c|c|c|c|c|c|c|c|}
\hline \multicolumn{2}{|c|}{$\begin{array}{l}\text { Parameters } \\
\end{array}$} & \multicolumn{2}{|c|}{$\begin{array}{l}\text { Plant height } \\
\text { (cm). }\end{array}$} & \multicolumn{2}{|c|}{$\begin{array}{l}\text { Plant fresh weight } \\
\text { (g.) }\end{array}$} & \multicolumn{2}{|c|}{$\begin{array}{c}\text { Plant dry weight } \\
\text { (g.) }\end{array}$} & \multicolumn{2}{|c|}{$\begin{array}{l}\text { No. of branches } \\
\text { per plant }\end{array}$} & \multicolumn{2}{|c|}{$\begin{array}{c}\text { Leaf } \\
\text { chlorophyll content } \\
\text { (SPAD unit) }\end{array}$} \\
\hline \multirow{2}{*}{\multicolumn{2}{|c|}{ Bronco }} & & & & & & & & & & \\
\hline & & 36.43 & 35.64 & 38.26 & 39.26 & 6.77 & 6.90 & 3.22 & 3.33 & 31.21 & 34.06 \\
\hline \multicolumn{2}{|c|}{ Paulista } & 38.02 & 38.12 & 56.99 & 52.23 & 9.87 & 9.67 & 4.39 & 4.00 & 33.47 & 35.32 \\
\hline \multicolumn{2}{|c|}{ L.S.D. at 0.05} & 1.58 & 1.01 & 1.87 & 1.38 & 0.46 & 0.38 & 0.51 & 0.45 & 2.18 & 1.07 \\
\hline \multicolumn{12}{|c|}{ Treatments } \\
\hline \multicolumn{2}{|c|}{ Control (uninoculated) } & 34.97 & 32.83 & 39.74 & 36.00 & 7.41 & 7.63 & 3.50 & 3.17 & 27.89 & 27.67 \\
\hline \multicolumn{2}{|r|}{ Recommended (NPK) } & 38.28 & 36.73 & 48.17 & 46.33 & 8.49 & 8.42 & 3.84 & 3.50 & 33.94 & 36.40 \\
\hline \multicolumn{2}{|c|}{$\begin{array}{l}\text { Rhizobial inoculation ARC } 301 \text { (Rh)+ } \\
25 \% \text { NPK }\end{array}$} & 35.97 & 35.12 & 44.50 & 34.15 & 8.10 & 8.11 & 3.67 & 3.67 & 29.87 & 32.74 \\
\hline \multirow{4}{*}{\multicolumn{2}{|c|}{$\begin{array}{l}\text { Rh+Azotoacter }(\mathrm{AZ1})+25 \% \mathrm{NPK} \\
\text { Rh+B.megaterium }(\mathrm{BM})+25 \% \mathrm{NPK} \\
\text { Rh + AZ1 + BM3+ 25\% NPK } \\
\text { L.S.D. at } 0.05+25 \% \text { NPK }\end{array}$}} & 37.45 & 37.17 & 48.14 & 44.59 & 8.22 & 8.30 & 3.50 & 3.83 & 31.79 & 35.02 \\
\hline & & 39.22 & 41.55 & 54.02 & 53.89 & 9.25 & 8.79 & 4.34 & 4.00 & 36.00 & 38.55 \\
\hline & & 37.45 & 37.74 & 51.20 & 52.17 & 8.45 & 8.49 & 4.00 & $\mathbf{3 . 8 3}$ & 34.57 & 37.75 \\
\hline \multicolumn{11}{|c|}{ Interaction } & \\
\hline \multirow{5}{*}{ 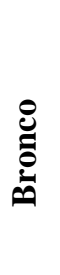 } & Control (uninoculated) & 33.43 & 30.43 & 33.07 & 36.83 & 5.79 & 6.05 & 3.33 & 3.00 & 26.27 & 24.57 \\
\hline & Recommended (NPK) & 36.13 & 35.13 & 37.60 & 38.52 & 6.87 & 7.03 & 3.00 & 3.33 & 32.70 & 36.97 \\
\hline & $\begin{array}{l}\text { Rhizobial inoculation ARC } 301(\text { Rh })+ \\
25 \% \text { NPK }\end{array}$ & 35.97 & 33.60 & 35.90 & 36.63 & 6.61 & 6.69 & 3.33 & 3.00 & 28.10 & 33.90 \\
\hline & Rh+Azotoacter $($ AZ1 $)+25 \%$ NPK & 36.83 & 35.33 & 38.37 & 38.77 & 6.38 & 6.87 & 2.67 & 3.33 & 29.60 & 34.37 \\
\hline & $\begin{array}{l}\text { Rh+ B.megaterium (BM3) }+25 \% \\
\text { NPK }\end{array}$ & 40.53 & 39.87 & 43.67 & 44.10 & 8.28 & 7.66 & 3.67 & 4.00 & 35.67 & 37.33 \\
\hline \multirow{7}{*}{ 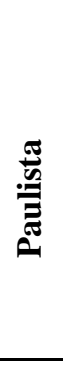 } & $\mathrm{Rh}+\mathrm{AZ1}+\mathrm{BM} 3+25 \% \mathrm{NPK}$ & 35.67 & 36.10 & 40.93 & 42.87 & 6.69 & 7.10 & $\mathbf{3 . 3 3}$ & $\mathbf{3 . 3 3}$ & 33.90 & 37.20 \\
\hline & Control (uninoculated) & 36.50 & 35.23 & 46.40 & 35.17 & 9.03 & 9.21 & 3.67 & 3.33 & 29.50 & 30.77 \\
\hline & Recommended (NPK) & 40.43 & 38.33 & 58.73 & 54.13 & 10.13 & 9.80 & 4.67 & 3.67 & 35.17 & 35.83 \\
\hline & $\begin{array}{l}\text { Rhizobial inoculation ARC } 301(\text { Rh })+ \\
25 \% \text { NPK }\end{array}$ & 36.97 & 36.63 & 53.10 & 49.67 & 9.58 & 9.52 & 4.00 & 4.33 & 31.63 & 31.57 \\
\hline & Rh+Azotoacter (AZ1) + 25\% NPK & 38.07 & 39.00 & $\mathbf{5 7 . 9 0}$ & 50.40 & 10.05 & 9.72 & 4.33 & 4.33 & 33.97 & 35.67 \\
\hline & $\begin{array}{l}\text { Rh+ B.megaterium (BM3) }+25 \% \\
\text { NPK }\end{array}$ & 41.90 & 42.83 & 64.37 & 63.67 & 10.22 & 9.92 & 5.00 & 4.33 & 36.33 & 39.77 \\
\hline & Rh + AZ1 + BM3+ 25\% NPK & 39.23 & 39.37 & 61.47 & 60.37 & 10.21 & 9.87 & 4.67 & 4.00 & 35.23 & 38.30 \\
\hline \multicolumn{2}{|c|}{ L.S.D. at 0.05 and N.S= non sig } & 4.02 & 2.48 & 4.59 & 3.38 & 1.13 & N.S & 1.25 & N.S & 5.34 & 2.61 \\
\hline
\end{tabular}


Table 3. Effect of rhizobial inoculation combined with Azotobacter chroococcum and Bacillus megaterium var phosphaticum on nodulation and $\mathrm{N}_{2}$-fixation of snap bean cultivars during 2007and 2008seasons.

\begin{tabular}{|c|c|c|c|c|c|c|c|c|c|c|c|c|}
\hline \multirow{3}{*}{ Treatments } & \multicolumn{4}{|c|}{$\begin{array}{l}\text { No. of nodules } \\
\text { plant }^{-1}\end{array}$} & \multicolumn{4}{|c|}{$\begin{array}{l}\text { Dry weight of nodules } \\
\text { mg plant }^{-1}\end{array}$} & \multicolumn{4}{|c|}{$*$ ARA $\mu$ mal $C_{2} \mathbf{H}_{4} \mathbf{h}^{-1}$ plant $^{-1}$} \\
\hline & \multicolumn{2}{|c|}{ Paulista } & \multicolumn{2}{|c|}{ Bronco } & \multicolumn{2}{|c|}{ Paulista } & \multicolumn{2}{|c|}{ Bronco } & \multicolumn{2}{|c|}{ Paulista } & \multicolumn{2}{|c|}{ Bronco } \\
\hline & $\begin{array}{c}\text { Season } \\
2007\end{array}$ & $\begin{array}{c}\text { Season } \\
2008\end{array}$ & $\begin{array}{c}\text { Season } \\
2007\end{array}$ & $\begin{array}{c}\text { Season } \\
2008\end{array}$ & $\begin{array}{c}\text { Season } \\
2007\end{array}$ & $\begin{array}{c}\text { Season } \\
2008\end{array}$ & $\begin{array}{c}\text { Season } \\
2007\end{array}$ & $\begin{array}{c}\text { Season } \\
2008\end{array}$ & $\begin{array}{c}\text { Season } \\
2007\end{array}$ & $\begin{array}{c}\text { Season } \\
2008\end{array}$ & $\begin{array}{c}\text { Season } \\
2007\end{array}$ & $\begin{array}{c}\text { Season } \\
2008\end{array}$ \\
\hline Control (uninoculated) & 2 & 3 & $\mathbf{0}$ & 4 & $\mathbf{0}$ & 1 & $\mathbf{0}$ & 2 & O & O & $\mathbf{0}$ & $\mathbf{0}$ \\
\hline Recommended (NPK) & $\mathbf{0}$ & 1 & $\mathbf{0}$ & 2 & $\mathbf{0}$ & $\mathbf{0}$ & $\mathbf{0}$ & $\mathbf{0}$ & $\mathbf{0}$ & $\mathbf{0}$ & $\mathbf{0}$ & $\mathbf{0}$ \\
\hline $\begin{array}{l}\text { Rhizobial inoculation ARC } \\
\text { 301 (Rh) + 25\% NPK }\end{array}$ & 43 & 50 & 40 & 56 & 174 & 190 & 164 & 170 & 181.340 & 140.45 & 93.925 & 103.250 \\
\hline $\begin{array}{l}\text { Rh+Azotoacter (AZ1) + 25\% } \\
\text { NPK }\end{array}$ & 59 & 49 & 57 & 48 & 189 & 160 & 180 & 197 & 132.791 & 135.240 & 133.420 & 124.426 \\
\hline $\begin{array}{l}\text { Rh+ B.megaterium }(\mathrm{BM})+ \\
25 \% \text { NPK }\end{array}$ & 45 & 68 & 42 & 62 & 150 & 199 & 143 & 169 & 120.153 & 143.820 & 177.325 & 140.372 \\
\hline $\begin{array}{l}\text { Rh + AZ1 + BM3+ 25\% } \\
\text { NPK }\end{array}$ & 77 & 80 & 64 & 78 & 247 & 250 & 205 & 223 & 140.253 & 150.342 & 111.472 & 120.375 \\
\hline L.S.D. at 0.05 & 5.0 & 6.0 & 5.0 & 6.0 & 22 & 25 & 20 & 20 & 10.15 & 10.45 & 9.62 & 11.47 \\
\hline
\end{tabular}

*Acetylene Reduction Assay. 


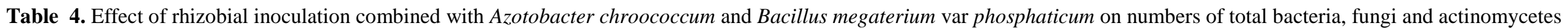
of snap bean rhizosphers during 2007 and 2008 seasons.

\begin{tabular}{|c|c|c|c|c|c|c|}
\hline \multirow[t]{2}{*}{ Treatments } & \multicolumn{2}{|c|}{$\begin{array}{c}\text { Fungi } \\
(\log \text { number })\end{array}$} & \multicolumn{2}{|c|}{$\begin{array}{c}\text { Actenomycetes } \\
\text { (log number) }\end{array}$} & \multicolumn{2}{|c|}{$\begin{array}{c}\text { Total bacteria } \\
\text { (log number) }\end{array}$} \\
\hline & Bronco & $\begin{array}{r}\text { Paulista } \\
\text { Season } 2007\end{array}$ & Bronco & Paulista & Bronco & Paulista \\
\hline Control (uninoculated) & 4.62 & 4.70 & 3.72 & 3.84 & 4.56 & 4.95 \\
\hline Recommended (NPK) & 3.25 & 3.92 & 3.22 & 3.32 & 5.32 & 5.47 \\
\hline Rhizobial inoculation ARC $301(\mathrm{Rh})+25 \%$ NPK & 4.70 & 4.79 & 3.85 & 3.88 & 5.92 & 5.94 \\
\hline Rh+Azotoacter $(\mathbf{A Z 1})+25 \%$ NPK & 4.75 & 4.80 & 3.92 & 3.97 & 6.54 & 6.99 \\
\hline Rh+ B.megaterium (BM3) + 25\% NPK & 4.88 & 4.91 & 4.32 & 4.56 & 7.25 & 7.50 \\
\hline \multirow[t]{2}{*}{ Rh + AZ1 + BM3+ 25\% NPK } & 4.90 & 4.99 & 4.57 & 4.59 & 7.82 & 7.90 \\
\hline & \multicolumn{4}{|c|}{ Season 2008} & & \\
\hline Control (uninoculated) & 4.73 & 4.80 & 3.84 & 3.86 & 4.60 & 5.02 \\
\hline Recommended (NPK) & 3.53 & 4.02 & 3.34 & 3.35 & 4.99 & 5.52 \\
\hline Rhizobial inoculation ARC $301(\mathrm{Rh})+25 \%$ NPK & 4.62 & 4.82 & 3.90 & 3.90 & 5.99 & 6.01 \\
\hline Rh+Azotoacter (AZ1) + 25\% NPK & 4.77 & 4.81 & 3.92 & 3.92 & 6.72 & 6.98 \\
\hline Rh+ B.megaterium (BM3) + 25\% NPK & 4.85 & 4.89 & 4.45 & 3.99 & 7.32 & 7.62 \\
\hline $\mathrm{Rh}+\mathrm{AZ1}+\mathrm{BM3}+25 \% \mathrm{NPK}$ & 4.93 & 4.99 & 4.60 & 4.42 & 7.92 & 7.49 \\
\hline
\end{tabular}


Yield and its components:

Data presented in Table (5) indicated that pod number per plant of cv. Paulista was higher than that of cv. Bronco, while the reverse was true for pod yield per plant. On the other hand, Bronco cv. exceeded Paulista cv. in early and total green yield per feddan. Dry seed yield per feddan showed the same trend of green pod yield in both studied cultivars.

As shown in Table (5) there were significant differences among the bacterial inoculation for all tested traits of yield and its components. Snap bean Plants treated with rhizobial inoculation + B.megaterium (BM3) $+25 \%$ NPK, produced significantly higher values of plant green pod yield, early and total green pod yield per feddan as well as dry seed yield. On the other hand, Rh + AZ1 + BM3 $+25 \%$ NPK significantly increased the plants green pod yield as well as dry seed yield compared with uninoculated control and recorded nearly equal values of the treatment of $100 \%$ NPK. Concerning the interaction between cultivars and bacterial inoculation, the treatment of $\mathrm{Rh}+$ B.megaterium $(\mathrm{BM} 3)+25 \% \mathrm{NPK}$, followed by the treatment of $\mathrm{Rh}+\mathrm{AZ1}+\mathrm{BM} 3+25 \%$ NPK for cv. Bronco significantly increased the plant yield, early and total green pod yields as well as dry seed yield. Also, the treatments of $100 \%$ NPK or Rh + Azotobacter $(\mathrm{AZ1})+$ $25 \%$ NPK led to significant higher values of plant green yield and dry seed yield. Meanwhile, in cv. Paulista plants received $\mathrm{Rh}+\mathrm{BM} 3+25 \%$ NPK produced the highest values of plant green yield and dry seed yield. Also, the treatment of Rh $+\mathrm{AZ} 1+\mathrm{BM} 3+25 \% \mathrm{NPK}$ followed by $100 \%$ NPK (without biofertilizers) significantly increased dry seed yield comparing with the uninoculated control.

The increase in total green pod and dry seed yields might be attributed to the favourable effect of rhizobium inoculation. Similar conclusions were previously reported by Aryal et al. (2003) who found that common bean can meet the plant nitrogen requirements by symbiotic $\mathrm{N}_{2^{-}}$ fixation. The percentage of $\mathrm{N}$ derived from atmospheric of field grown with Phasealus vulgaris was between $38 \%$ and $68 \%$. On the other hand, Mikanova et al., (1995) and Ismail (2002) revealed that pea yield increased with the use of phosphate solubilizing inoculation in the absence of fertilizer to a level similar to that obtained with $45 \mathrm{~kg}$ $\mathrm{P} /$ ha alone. The obtained results are in harmony with those reported by Abd El-Fattah and Arisha (2000) and Shehata et al., (2007).

\section{Green pod characters:}

As shown in Table (6) Bronco cv. overcame cv. Paulista in pod weight and diameter, dry matter, carbohydrate and fibres content in both seasons. There were no noticeable differences between the two snap bean cultivars concerning pod length as well as protein percentage. Also, there were significant differences among the bacterial inocula for all studied characters of the green pods. The treatments $\mathrm{Rh}+\mathrm{BM} 3+25 \% \mathrm{NPK}, \mathrm{Rh}+\mathrm{AZ} 1$ $\mathrm{BM} 3+25 \%$ NPK or $100 \% \mathrm{NPK}$ led to the highest values of green pod characters in both seasons.

In the case of $\mathrm{cv}$. Bronco, the treatments of $\mathrm{Rh}+\mathrm{BM} 3+25 \% \mathrm{NPK}, \mathrm{Rh}+\mathrm{AZ} 1+\mathrm{BM} 3+$ $25 \%$ NPK and $100 \%$ NPK significalty increased pod weight and length compared to uninoculated control. Meanwhile, in cv. Paulsita the treatment of $\mathrm{Rh}+\mathrm{BM} 3+25 \%$ led to the highest pod weight and length. There were no remarkable differences between all tested treatments in both cultivars regarding pod diameter. In addition, treatment of $\mathrm{Rh}$ rhizobium $+25 \%$ NPK significantly increased pods dry matter content, protein, charbohydrats and fibers (exceeded or approximately equal to $100 \%$ NPK) in both cultivars compared to uninoculated control. The present results confirmed those of El-Sayed (1990) who found differences among some common bean cultivars regarding, crude fibers and protein content. Similarly, Singer et al. (1996) mentioned that a mixture of three biofertilizers, in general, gave the highest physical properties of snap bean pods even with different levels of NPK applications. Also, other investigators indicated positive effects of Rhizobium and Azospirillum on plant growth, yield and chemical components of snap been pods (Singer et al., 2000; Shehata et al., 2007).

\section{Leaves and pods elemental ( $N, P$ and $K$ ) concentration:}

As shown in Table (7)snap bean plants cv. Paulista was greater than those of $\mathrm{cv}$. Bronco in leaves content of $\mathrm{N}$ and $\mathrm{K}$ as well as pods content of $\mathrm{N}, \mathrm{P}$ and $\mathrm{K}$, the reverse was true concerning leaves content of P. Meanwhile, there were no remarkable differences between the two snap been cultivars concerning the leaves and pods content of $\mathrm{N}, \mathrm{P}$ and $\mathrm{K}$. Concerning rhizobium treatments, the treatment of $\mathrm{Rh}+\mathrm{BM} 3+25 \% \mathrm{NPK}$ followed by $\mathrm{Rh}+\mathrm{AZ} 1+$ $\mathrm{BM} 3+25 \%$ NPK significantly gave the higher value of leaves content of $\mathrm{N}$ and $\mathrm{K}$ as well as pods content of $\mathrm{N}$ and $\mathrm{P}$ comparing with the unioculated control. On the other hand, plants treated with $\mathrm{Rh}+\mathrm{AZ1}+$ $\mathrm{BM} 3+25 \%$ NPK produced the highest values of leaves content of $\mathrm{P}$ in both seasons, while the treatment of $\mathrm{Rh}+\mathrm{BM} 3+25 \% \mathrm{NPK}$ led to the highest values of pods content of $\mathrm{K}$ compared to the uninoculated control or the treatment of $100 \%$ NPK. Regarding the interaction, it was clear that in $\mathrm{cv}$. Bronco there were no significant differences among the treatments concerning leaves content of $\mathrm{N}$ or $\mathrm{P}$, meanwhile the treatments Rh $+\mathrm{BM} 3+25 \% \mathrm{NPK}$ or $\mathrm{Rh}+\mathrm{AZ1}+\mathrm{BM} 3+25 \%$ NPK significantly increased pods content of $\mathrm{N}, \mathrm{P}$ and $\mathrm{K}$ as well as leaves content of $\mathrm{K}$. In cv. Paulista, plants treated with $\mathrm{Rh}+\mathrm{BM} 3+25 \% \mathrm{NPK}$ or $\mathrm{Rh}+\mathrm{AZ} 1+\mathrm{BM} 3+$ $25 \%$ NPK significantly increased the leaves and pods content of $\mathrm{N}, \mathrm{P}$ and $\mathrm{K}$ in both seasons compared to the uninoculated control. 
Table 5: Effect of bacterial strains on yield of snap bean cultivars during 2007 and 2008 seasons.

\begin{tabular}{|c|c|c|c|c|c|c|c|c|c|c|c|}
\hline \multirow{2}{*}{\multicolumn{2}{|c|}{$\begin{array}{ll}\text { Cultivars } & \text { Parameters } \\
\end{array}$}} & \multirow{2}{*}{\multicolumn{4}{|c|}{ Green pods yield/plant }} & \multicolumn{4}{|c|}{ Green pods yield (ton/fed.) } & \multirow{2}{*}{\multicolumn{2}{|c|}{$\begin{array}{l}\text { Dry seed yield } \\
\text { (ton / fed). }\end{array}$}} \\
\hline & & & & & & \multicolumn{2}{|c|}{ Early } & \multicolumn{2}{|c|}{ Total } & & \\
\hline & & \multicolumn{2}{|c|}{ Weight (g.) } & \multicolumn{2}{|c|}{ No. of pods } & \multirow[b]{2}{*}{2007} & \multirow[b]{2}{*}{2008} & \multirow[b]{2}{*}{2007} & \multirow[b]{2}{*}{2008} & \multirow[b]{2}{*}{2007} & \multirow[b]{2}{*}{2008} \\
\hline & & 2007 & 2008 & 2007 & 2008 & & & & & & \\
\hline \multicolumn{2}{|c|}{ Bronco } & 73.13 & 73.84 & 18.06 & 19.00 & 0.55 & 0.56 & 3.58 & 3.60 & 0.77 & 0.79 \\
\hline \multicolumn{2}{|c|}{ Paulista } & 67.74 & 68.44 & 20.78 & 20.06 & 0.48 & 0.50 & 3.21 & 3.29 & 0.69 & 0.69 \\
\hline \multicolumn{2}{|c|}{ L.S.D. at 0.05} & 3.96 & 4.00 & 1.22 & 1.03 & 0.05 & 0.06 & 0.33 & 0.31 & 0.07 & 0.07 \\
\hline \multicolumn{12}{|c|}{ Treatments } \\
\hline \multicolumn{2}{|c|}{ Control (uninoculated) } & 64.12 & 64.65 & 18.34 & 17.84 & 0.46 & 0.48 & 3.03 & 3.10 & 0.49 & 0.54 \\
\hline \multicolumn{2}{|r|}{ Recommended (NPK) } & 75.52 & 73.79 & 20.00 & 20.17 & $\mathbf{0 . 5 3}$ & 0.54 & 3.36 & 3.55 & 0.73 & 0.77 \\
\hline \multicolumn{2}{|r|}{$\begin{array}{l}\text { Rhizobial inoculation ARC } 301(\mathrm{Rh})+25 \% \\
\text { NPK }\end{array}$} & 65.35 & 65.35 & 18.50 & 18.67 & 0.50 & 0.51 & 3.32 & 3.36 & 0.60 & 0.60 \\
\hline \multicolumn{2}{|r|}{ Rh+Azotoacter $(\mathrm{AZ1})+25 \%$ NPK } & 66.68 & 68.68 & 19.00 & 19.84 & 0.52 & 0.52 & 3.44 & 3.40 & 0.67 & 0.68 \\
\hline \multicolumn{2}{|c|}{$\mathrm{Rh}+$ B.megaterium $(\mathrm{BM})+25 \% \mathrm{NPK}$} & 79.02 & 78.77 & 21.00 & 21.00 & 0.56 & 0.58 & 3.71 & 3.59 & 0.96 & 0.97 \\
\hline \multicolumn{2}{|c|}{$\mathrm{Rh}+\mathrm{AZ1}+\mathrm{BM} 3+25 \% \mathrm{NPK}$} & 71.94 & 75.69 & 19.67 & 19.69 & 0.54 & 0.54 & 3.56 & 3.58 & 0.92 & 0.90 \\
\hline \multicolumn{2}{|c|}{ L.S.D. at 0.05} & 6.86 & 6.93 & 2.11 & 1.84 & 0.09 & 0.10 & 0.59 & 0.47 & 0.12 & 0.12 \\
\hline \multicolumn{12}{|c|}{ Interaction } \\
\hline \multirow{6}{*}{$\underset{0}{\stackrel{0}{0}}$} & Control (uninoculated) & 65.87 & 65.97 & 16.67 & 17.00 & 0.44 & 0.46 & 2.92 & 3.04 & 0.54 & 0.57 \\
\hline & Recommended (NPK) & 82.40 & $\mathbf{7 5 . 7 0}$ & 19.33 & 19.33 & 0.55 & 0.57 & 3.59 & 3.76 & 0.80 & 0.83 \\
\hline & $\begin{array}{l}\text { Rhizobial inoculation ARC } 301(\text { Rh })+25 \% \\
\text { NPK }\end{array}$ & 66.47 & 66.63 & 17.00 & 18.33 & 0.51 & 0.52 & 3.38 & 3.46 & 0.70 & 0.71 \\
\hline & Rh+Azotoacter $(A Z 1)+25 \%$ NPK & 66.53 & 70.03 & 17.67 & 19.67 & 0.55 & 0.53 & 3.60 & 3.49 & 0.76 & 0.80 \\
\hline & $\mathrm{Rh}+$ B.megaterium $(\mathrm{BM} 3)+25 \% \mathrm{NPK}$ & 83.87 & 83.53 & 19.33 & 21.00 & 0.59 & 0.64 & 3.92 & 3.79 & 0.10 & 0.98 \\
\hline & $\mathrm{Rh}+\mathrm{AZ1}+\mathrm{BM} 3+25 \% \mathrm{NPK}$ & 83.67 & 81.17 & 18.33 & 18.68 & 0.58 & 0.57 & 3.79 & 3.78 & 0.88 & 0.87 \\
\hline \multirow{7}{*}{ 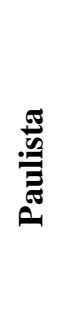 } & Control (uninoculated) & 62.37 & 63.33 & 20.00 & 18.67 & 0.48 & 0.50 & 3.13 & 3.16 & 0.44 & 0.50 \\
\hline & Recommended (NPK) & 68.63 & 71.87 & 20.67 & 21.00 & 0.50 & 0.51 & 3.15 & 3.35 & 0.66 & 0.70 \\
\hline & $\begin{array}{l}\text { Rhizobial inoculation ARC } 301(\text { Rh })+25 \% \\
\text { NPK }\end{array}$ & 64.23 & 64.07 & 20.00 & 19.00 & 0.48 & 0.50 & 3.25 & 3.27 & 0.49 & 0.50 \\
\hline & Rh+Azotoacter (AZ1) + 25\% NPK & 66.83 & 67.33 & 20.33 & 20.00 & 0.50 & 0.51 & 3.29 & 3.32 & 0.58 & 0.56 \\
\hline & $\mathrm{Rh}+$ B.megaterium $(\mathrm{BM} 3)+25 \% \mathrm{NPK}$ & 74.17 & 74.00 & 22.67 & 21.00 & $\mathbf{0 . 5 3}$ & 0.52 & 3.51 & 3.39 & 0.98 & 0.95 \\
\hline & $\mathrm{Rh}+\mathrm{AZ1}+\mathrm{BM} 3+\mathbf{2 5 \%} \mathrm{NPK}$ & 70.20 & 70.03 & 21.00 & 20.68 & 0.49 & 0.51 & 3.32 & 3.38 & 0.95 & 0.93 \\
\hline & L.S.D. at 0.05 & 9.70 & 9.79 & 2.58 & 2.30 & 0.13 & 0.13 & 0.84 & 0.74 & 0.17 & $\mathbf{0 . 1 7}$ \\
\hline
\end{tabular}


Table 6: Effect of bacterial strains on pod characteristics and chemical compounds of snap bean cultivars during 2007 and 2008 seasons.

\begin{tabular}{|c|c|c|c|c|c|c|c|c|c|c|c|c|c|c|c|}
\hline \multirow{3}{*}{\multicolumn{2}{|c|}{ Cultivars }} & \multicolumn{6}{|c|}{ Pod's characteristics } & \multicolumn{8}{|c|}{ Chemical compounds of snap bean pods } \\
\hline & & \multicolumn{2}{|c|}{$\begin{array}{c}\text { Weight } \\
\text { (g.) }\end{array}$} & \multicolumn{2}{|c|}{$\begin{array}{c}\text { Length } \\
\text { (cm.) }\end{array}$} & \multicolumn{2}{|c|}{$\begin{array}{c}\text { Width } \\
\text { (mm) }\end{array}$} & \multicolumn{2}{|c|}{$\begin{array}{c}\text { Dry matter } \\
\%\end{array}$} & \multicolumn{2}{|c|}{$\begin{array}{c}\text { Protein } \\
\% \\
\end{array}$} & \multicolumn{2}{|c|}{$\begin{array}{c}\text { Carbohydrate } \\
\%\end{array}$} & \multicolumn{2}{|c|}{$\begin{array}{c}\text { Fibers } \\
\%\end{array}$} \\
\hline & & 2007 & 2008 & 2007 & 2008 & 2007 & 2008 & 2007 & 2008 & 2007 & 2008 & 2007 & 2008 & 2007 & 2008 \\
\hline \multicolumn{2}{|c|}{ Bronco } & 3.91 & 4.05 & 11.94 & 11.83 & 88 & 87 & 10.63 & 10.42 & 22.36 & 22.07 & 60.72 & 60.56 & 10.34 & 10.27 \\
\hline \multicolumn{2}{|c|}{ Paulista } & 3.31 & 3.63 & 11.82 & 11.70 & 69 & 66 & 10.23 & 10.00 & 22.63 & 22.65 & 59.77 & 59.86 & 9.67 & 9.64 \\
\hline \multicolumn{2}{|c|}{ L.S.D. at 0.05} & 0.16 & 0.25 & 0.42 & 0.37 & 0.7 & 0.6 & 0.35 & 0.41 & N.S. & N.S. & 0.56 & 0.67 & 0.29 & 0.40 \\
\hline \multicolumn{16}{|c|}{ Treatments } \\
\hline \multicolumn{2}{|c|}{ Control (uninoculated) } & 3.20 & 3.37 & 11.17 & 11.24 & 70 & 70 & 9.27 & 9.65 & 21.33 & 20.68 & 56.12 & 56.29 & 9.07 & 9.38 \\
\hline \multicolumn{2}{|c|}{ Recommended (NPK) } & 3.73 & 3.81 & 12.19 & 12.12 & 82 & 81 & 11.19 & 10.90 & 23.07 & 22.52 & 61.90 & 61.69 & 10.37 & 10.32 \\
\hline \multicolumn{2}{|r|}{$\begin{array}{l}\text { Rhizobial inoculation ARC } 301(\mathrm{Rh})+ \\
25 \% \text { NPK }\end{array}$} & 3.37 & 3.55 & 11.33 & 11.40 & 74 & 72 & 9.80 & 10.02 & 21.37 & 21.29 & 75.62 & $\mathbf{5 7 . 8 7}$ & 9.50 & 9.48 \\
\hline \multicolumn{2}{|r|}{ Rh+Azotoacter $(\mathrm{AZ1})+\mathbf{2 5 \%}$ NPK } & 3.64 & 3.63 & 11.65 & 11.53 & 79 & 75 & 10.50 & 10.45 & 21.69 & 22.27 & 61.25 & 61.40 & 9.98 & 10.03 \\
\hline \multicolumn{2}{|r|}{$\mathrm{Rh}+$ B.megaterium $(\mathrm{BM})+25 \% \mathrm{NPK}$} & 3.88 & 4.07 & 12.69 & 12.34 & 88 & 82 & 11.25 & 10.94 & 24.55 & 24.20 & 63.07 & 62.43 & 10.73 & 10.47 \\
\hline \multicolumn{2}{|c|}{$\mathrm{Rh}+\mathrm{AZ1}+\mathrm{BM} 3+25 \% \mathrm{NPK}$} & 3.85 & 3.85 & 12.27 & 11.97 & 80 & 79 & 10.58 & 10.57 & 22.95 & 23.22 & 61.53 & 61.57 & $\mathbf{1 0 . 3 7}$ & 10.07 \\
\hline \multicolumn{2}{|c|}{ L.S.D. at 0.05} & 0.27 & $\mathbf{0 . 4 3}$ & 0.73 & 0.65 & 10 & 11 & 0.60 & 0.72 & 0.89 & 1.17 & 0.97 & 1.15 & 0.49 & 0.70 \\
\hline \multicolumn{16}{|c|}{ Interaction } \\
\hline \multirow{5}{*}{$\begin{array}{l}\stackrel{\circlearrowright}{0} \\
\ddot{D}\end{array}$} & Control (uninoculated) & 3.50 & 3.73 & 11.13 & 11.20 & 88 & 80 & 9.10 & 9.33 & 21.13 & 20.53 & 57.40 & 57.77 & 9.53 & 9.83 \\
\hline & Recommended (NPK) & 4.13 & 4.07 & 12.50 & 12.27 & 90 & 93 & 11.70 & 11.23 & 22.83 & 22.27 & 62.10 & 61.67 & 10.53 & 10.73 \\
\hline & $\begin{array}{l}\text { Rhizobial inoculation ARC } 301 \text { (Rh) } \\
+25 \% \text { NPK }\end{array}$ & 3.60 & 3.87 & 11.33 & 11.50 & 80 & 80 & 10.10 & 9.60 & 21.17 & 20.80 & $\mathbf{5 8 . 4 7}$ & $\mathbf{5 8 . 6 0}$ & 10.07 & 9.97 \\
\hline & Rh+Azotoacter $(\mathrm{AZ1})+25 \% \mathrm{NPK}$ & 4.00 & 4.03 & 11.70 & 11.53 & 87 & 83 & $\mathbf{1 0 . 5 0}$ & 10.43 & 21.77 & 22.37 & 61.47 & 61.63 & 10.33 & 10.10 \\
\hline & $\begin{array}{l}\text { Rh+B.megaterium (BM3) }+25 \% \\
\text { NPK }\end{array}$ & 4.13 & 4.50 & 12.87 & 12.57 & 103 & 93 & 11.73 & 11.27 & 24.83 & 24.90 & 63.27 & 63.03 & 11.13 & 10.87 \\
\hline \multirow{8}{*}{ 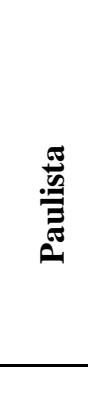 } & $\mathbf{R h}+\mathbf{A Z 1}+\mathbf{B M 3}+25 \% \mathrm{NPK}$ & 4.10 & 4.10 & 12.47 & 11.90 & 90 & 90 & 10.63 & 10.63 & 22.90 & 23.07 & 61.63 & 61.83 & 10.43 & 10.13 \\
\hline & Control (uninoculated) & 2.90 & 3.00 & 11.20 & 11.27 & 63 & 60 & 9.43 & 9.97 & 21.53 & 20.38 & 54.83 & 54.80 & 8.60 & 8.93 \\
\hline & Recommended (NPK) & 3.33 & 3.53 & 11.87 & 11.97 & 73 & 67 & 10.67 & 10.57 & 23.30 & 22.77 & 61.70 & 61.70 & 10.20 & 9.90 \\
\hline & $\begin{array}{l}\text { Rhizobial inoculation ARC } 301 \text { (Rh) } \\
+25 \% \text { NPK }\end{array}$ & 3.13 & $\mathbf{3 . 2 3}$ & 11.33 & 11.30 & 67 & 63 & 9.50 & 10.43 & 21.27 & 22.17 & 56.77 & 57.13 & 8.93 & 9.00 \\
\hline & Rh+Azotoacter $(\mathrm{AZ1})+\mathbf{2 5 \%} \mathrm{NPK}$ & 3.27 & 3.23 & 11.60 & 11.53 & 70 & 67 & 10.50 & 10.47 & 21.60 & 22.17 & 61.03 & 61.17 & 9.63 & 9.97 \\
\hline & $\begin{array}{l}\text { Rh+B.megaterium }(\mathrm{BM})+25 \% \\
\mathrm{NPK}\end{array}$ & 3.63 & 3.63 & 12.50 & 21.10 & 73 & 70 & 10.77 & 10.60 & 24.77 & 24.00 & 62.87 & 61.83 & 10.33 & 10.07 \\
\hline & $\mathbf{R h}+\mathbf{A Z 1}+\mathbf{B M 3}$ & 3.60 & 3.50 & 12.07 & 12.03 & 70 & 67 & 10.53 & 10.50 & 23.00 & 23.37 & 61.43 & 61.30 & 10.30 & 10.00 \\
\hline & L.S.D. at 0.05 & 0.38 & 0.61 & 1.04 & 0.82 & 16 & 15 & 0.85 & 1.01 & 1.27 & 1.66 & 1.37 & 1.63 & $\mathbf{0 . 7 0}$ & 0.98 \\
\hline
\end{tabular}


Table 7: Effect of bacterial strains on N, P and concentrations (\%) of snap bean leaves and pods during 2007 and 2008 seasons.

\begin{tabular}{|c|c|c|c|c|c|c|c|c|c|c|c|c|c|}
\hline \multirow{3}{*}{\multicolumn{2}{|c|}{ Cultivars }} & \multicolumn{6}{|c|}{ Leaves NPK (\%) } & \multicolumn{6}{|c|}{ Pods NPK (\%) } \\
\hline & & \multicolumn{2}{|c|}{ Nitrogen } & \multicolumn{2}{|c|}{ Phosphours } & \multicolumn{2}{|c|}{ Potassium } & \multicolumn{2}{|c|}{ Nitrogen } & \multicolumn{2}{|c|}{ Phosphorus } & \multicolumn{2}{|c|}{ Potassium } \\
\hline & & 2007 & 2008 & 2007 & 2008 & 2007 & 2008 & 2007 & 2008 & 2007 & 2008 & 2007 & 2008 \\
\hline \multicolumn{2}{|c|}{ Bronco } & 1.96 & 2.09 & 0.63 & 0.67 & 2.18 & 2.21 & 3.58 & 3.53 & 0.55 & 0.51 & 2.71 & 2.69 \\
\hline \multicolumn{2}{|c|}{ Paulista } & 2.18 & 2.23 & 0.59 & 0.63 & 2.32 & 2.37 & 3.61 & 3.62 & 0.58 & 0.60 & 3.01 & 2.98 \\
\hline \multicolumn{2}{|c|}{ L.S.D. at 0.05} & N.S. & N.S & N.S & N.S & N.S & N.S & N.S & N.S & N.S & N.S & N.S & N.S \\
\hline \multicolumn{14}{|c|}{ Treatments } \\
\hline \multicolumn{2}{|c|}{ Control (uninoculated) } & 1.88 & 1.78 & 0.58 & 0.60 & 2.31 & 2.28 & 3.41 & 3.31 & 0.57 & 0.54 & 2.78 & 2.81 \\
\hline \multicolumn{2}{|c|}{ Recommended (NPK) } & 1.96 & 2.01 & 0.52 & 0.61 & 2.11 & 2.06 & 3.69 & 3.60 & 0.58 & 0.56 & 2.80 & 2.72 \\
\hline \multicolumn{2}{|c|}{$\begin{array}{l}\text { Rhizobial inoculation ARC } 301(\mathrm{Rh})+25 \% \\
\text { NPK }\end{array}$} & 2.01 & 1.99 & 0.58 & 0.52 & 2.43 & 2.39 & 3.42 & 3.41 & $\mathbf{0 . 5 0}$ & 0.51 & 2.67 & 2.61 \\
\hline \multicolumn{2}{|c|}{ Rh+Azotoacter $(\mathrm{AZ1})+25 \%$ NPK } & 2.19 & 2.16 & $0 . .61$ & 0.58 & 2.50 & 2.54 & 3.47 & 3.56 & 0.63 & 0.60 & 2.74 & 2.80 \\
\hline \multicolumn{2}{|c|}{$\mathrm{Rh}+$ B.megaterium $(\mathrm{BM})+25 \% \mathrm{NPK}$} & 2.41 & 2.33 & 0.64 & 0.66 & 2.99 & 2.92 & 3.93 & 3.87 & 0.73 & 0.69 & 3.11 & 3.00 \\
\hline \multicolumn{2}{|c|}{$\mathbf{R h}+\mathbf{A Z 1}+\mathbf{B M 3}+25 \% \mathrm{NPK}$} & 2.18 & 2.11 & 0.68 & 0.72 & 2.80 & 2.73 & 3.67 & 3.72 & 0.71 & 0.68 & 2.91 & 2.99 \\
\hline \multicolumn{2}{|c|}{ L.S.D. at 0.05} & 0.26 & 0.31 & 0.09 & 0.11 & 0.46 & 2.39 & 0.19 & 0.27 & 0.09 & 0.12 & 0.23 & 0.18 \\
\hline \multicolumn{14}{|c|}{ Interaction } \\
\hline \multirow{6}{*}{ 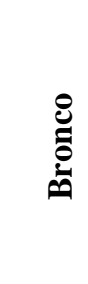 } & Control (uninoculated) & 1.94 & 1.93 & 0.48 & 0.51 & 2.50 & 2.57 & 3.38 & 3.28 & 0.58 & 0.56 & 2.69 & 2.73 \\
\hline & Recommended (NPK) & 2.01 & 2.10 & 0.55 & $\mathbf{0 . 5 0}$ & 2.44 & 2.53 & 3.85 & 3.16 & 0.63 & 0.61 & 2.58 & 2.61 \\
\hline & $\begin{array}{l}\text { Rhizobial inoculation ARC } 301 \text { (Rh) + } \\
25 \% \text { NPK }\end{array}$ & 2.26 & 2.21 & 0.57 & 0.51 & 2.61 & 2.63 & 3.39 & 3.33 & 0.60 & 0.56 & 2.80 & 2.75 \\
\hline & Rh+Azotoacter $(A Z 1)+25 \%$ NPK & 2.22 & 2.17 & 0.60 & 0.62 & 2.71 & 2.76 & 3.48 & 3.58 & 0.63 & 0.61 & 2.90 & 2.87 \\
\hline & $\mathrm{Rh}+$ B.megaterium $(\mathrm{BM} 3)+25 \% \mathrm{NPK}$ & 2.18 & 2.29 & 0.62 & 0.65 & 2.81 & 2.90 & 3.97 & 3.98 & 0.79 & 0.81 & 3.16 & 3.24 \\
\hline & $\mathrm{Rh}+\mathrm{AZ1}+\mathrm{BM} 3+\mathbf{2 5 \%} \mathrm{NPK}$ & 2.16 & 2.21 & $\mathbf{0 . 7 0}$ & 0.72 & 2.96 & 2.91 & 3.66 & 3.69 & 0.77 & 0.47 & 3.10 & 3.06 \\
\hline \multirow{7}{*}{ 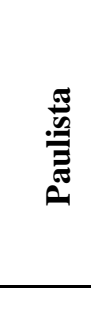 } & Control (uninoculated) & 1.87 & 1.92 & $\mathbf{0 . 5 3}$ & 0.56 & 2.62 & 2.71 & 3.44 & 3.33 & 0.52 & 0.58 & 2.96 & 2.88 \\
\hline & Recommended (NPK) & 2.19 & 2.24 & 0.58 & 0.49 & 2.71 & 2.67 & 3.03 & $3 . .24$ & 0.55 & 0.59 & 2.80 & 2.72 \\
\hline & $\begin{array}{l}\text { Rhizobial inoculation ARC } 301 \text { (Rh) + } \\
25 \% \text { NPK }\end{array}$ & 2.02 & 2.29 & 0.55 & 0.58 & 2.70 & 2.82 & 3.45 & 3.48 & 0.60 & 0.64 & 2.91 & 2.88 \\
\hline & Rh+Azotoacter $(\mathrm{AZ1})+25 \%$ NPK & 2.17 & 2.23 & 0.61 & 0.65 & 2.87 & 2.92 & 3.46 & 3.54 & 0.67 & 0.66 & 3.01 & 2.96 \\
\hline & $\mathrm{Rh}+$ B.megaterium $(\mathrm{BM} 3)+25 \%$ NPK & 2.46 & 2.35 & 0.84 & 0.79 & 3.08 & 2.99 & 3.96 & 3.84 & 0.82 & 0.77 & 3.69 & 3.52 \\
\hline & $\mathrm{Rh}+\mathrm{AZ1}+\mathrm{BM} 3+25 \% \mathrm{NPK}$ & 2.30 & 2.34 & 0.79 & $\mathbf{0 . 8 0}$ & 3.11 & 3.06 & 3.68 & 3.74 & 0.80 & 0.79 & 3.30 & 3.38 \\
\hline & L.S.D. at 0.05 & 0.32 & 0.40 & 0.21 & 0.21 & 0.38 & 0.33 & 0.20 & 0.22 & 0.17 & 0.15 & 0.41 & 0.39 \\
\hline
\end{tabular}


The present results confirmed those of Aryal et al. (2003) and Shehata et al. (2007) who reported that inoculation of snap bean with Rhizobium Azosirillum or arbuscular mycorrhizal fungi (AMF) increased leaves content of $\mathrm{N}$ and the chemical composition of pods in addition to improve nutrient uptake. The positive effects of inoculation with Azospirillum brasilense on plant growth, and consequently on yield and pod characters could be explained by an enhancement of root branching and root growth. These favorable effects on root growth are known to improve the efficiency of mineral and water uptake, and consequently protein production and hormonal activity in inoculated plants (Hamaoui et al., 2001). Additionally, the positive effect of increased phosphorus absorption by bean plants as a result of inoculation with Okadine + Rhizobacterin on vegetative growth may be due to the beneficial effect of $\mathrm{P}$ element on the activation of photosynthesis and metabolic processes of organic compounds in plants and hence increasing plant growth (Gardener et al., 1985). Also, the enhancing effect of nitrogen absorption on plant growth may be due to the positive effects of N-element on activating photosynthesis and metabolic processes of organic compounds in plants which in turn, encourage the plant vegetative growth, which exert direct effect on the yield (El-Seifi et al., 2004).

\section{References}

A.O.A.C. Methods. (1980). Official Method of Analysis of Chemist. $13^{\text {th }}$ Ed. Washington, D.C.

Abd El-Fattah, H.I. and Arisha., H.M. (2000). Effect of Rhizobium inoculation and vitamin $\mathrm{B}_{12}$ on growth, yield and quality of common bean under sandy soil conditions. Zagazig J. Agric. Res., 27(1): 59-76.

Aryal, U.K.; XU H.L.and Fujita, M. (2003). Rhizobia and AM fungal inoculation improve growth and nutrient uptake of bean plants under organic fertilization. J. Sustainable Agric., 21(3) 29-41.

Ashrafuzzaman ,M., F. A. ,Hossen; R. I. M., Anamul Hoque Md.; Zahurul Islam S.M., Shahidullah, S.M. and Sariah, M.A. (2009). Efficiency of plant growth-promoting rhizobacteria (PGPR) for the enhancement of rice growth. African Jornal of Biotechnology. 8 (7), pp. 1247-1252, 6.

Brown, J.D. and Lilliland, O. (1964). Rapid determination of potassium and sodium in plant material and soil extracts by flame photometry. Proc. Amer. Soc. Hort. Sci., 48: 341-346.

Bunt, J.S. and Rovira, A.D. (1955). Microbiological studies of some subantarctic soils. J. Soil, 6:119-128.

Carvalho, E.G. de., Arfo., Sa M.E. de. and Buzetti, S. (1998). Effects of nitrogen, molybdenum and seed inoculation on bean (Phaseolus vulgaris L.) Crop at Selviria, MS. II. Physiological quality and felid performance of been seeds. CientificaJaboticabal 26: 59-71.

Chrispeels, M.J. and Sadava, D.E. (1994). Plants, Genes and Agriculture. Jones and Bartlett Publishers, Boston, London. 187-239.

Daba, S. and Haile, M. (2002). Effects of rhizobial inoculant and nitrogen fertilizer on yield and nodulation of common bean under intercropped condition. J. Plant Nutr., 23:581591.

Datt, N.; Rana, M.C. and Sharma, R.P. (2006). Effect of seed inoculation and farmyard manuring on nitrogen balance and yield in rajmash (Phaseolus vulgaris). Indian J. Plant Physiology. 11: 108-112.

El-Sayed, S.F.; (1990). Comparative study on some common bean cultivars. II. Chemical compositions. J. Agric. Res. Tanta Univ., 16: 501-510.

El-Seifi S.K., Sarg S.M.H.; Abdel-Fattah ,A.L. and Mohamed,M.A. (2004). Effect of biofertilizers and nitrogen levels on the productivity and quality of Chinese garlic under sandy soil conditions. Zagazig J. Agric. Res., 31(3).

Gardener, F.D.; Pearce R.B. and Mitchell, R.L. (1985). Physiology of crop plants. The Iowa state Univ., Press, Amer. 327.

Gupta, S.; Arona, D.K. and Srivastava, A.K. (1995). Growth promotion of tomato plants by rhizobacteria and imposition of energy stress on Rhizoctonia solani. Soil Biology and Biochem., 27: 1051-1058.

Hamaoui, B.; Abbadi J.M.; Burdman, S.; Rashid, A.; Sarig, S. and Okon, Y. (2001). Effects of inoculation with Azospirillum brasilense on chickpeas (Cicer artietnum) and Faba beans (Vicia faba) under different growth conditions, Agronomine 21: 553-560.

Hardy, R.W.F.; Bums, B.C. and Hostem, R.U. (1973). Application of the acetylene ethylene assay for measurement of nitrogen fixation. Soil Biol. Biochem. 5:47 - 81 .

Hegazi, N.A. and Neimela, S. (1976). A note on the estimation of Azotobacter densities by membrane filters technique. J. Appl. Bacteiol., 41: 311-313.

Hernandez-Armenta , R.; Wein, H.C. and Eaglesham, A.R. (1989). Maximum temperature for nitrogen fixation in common bean. Crop Sci., 29: 1260-1265.

Huphries, E.C. (1956). Mineral components and ash analysis (In. Modern method of plant Analysis, Edit by K-Peach and M.V. Tracey). Springier Verlag Berlin, 1: 468.

Ismail, R.H.A. (2002). Physiological studies on biofertilization in pea plants (Pisum sativum L.) under calcareous soil conditions. Ph.D. Thesis, Fac. Agric. Cairo Univ. 446 pp. 
Jackson, M.L. (1958). Soil Chemical Analysis. Prentice-Hall. Inc., Englewood Cliffs, N.J., U.S.A.

Lalande, R.; Bigwaneza, P.C. and Antoun, H. (1990). Symbiotic effectiveness of strains of Rhizobium leguminosarum biovar Phaseoli isolated from soils of Rwanda. Plant and Soil, 121: 41-46.

Mikanova, O.; Kubat J.; Vorisek ,K. and Randova, D. (1995). The capacity of the strains Rhizobium leguminosarum to make phosphorus available. Rostlinna Vyroba 41: 423-425.

Moawad, H.; Badr El-Din, S.M.S.; Abdel-Aziz, R.H. and Hardarson, G. (1998). Improvement of biological nitrogen fixation in Egyptian winter legumes through better management of Rhizobium plant and soil 204(1): 95-106.

Ragab , Mona A.A.; Abotaleb H.H.; Nadia M.A.and Ghalb S. (2006). Response of lupine plants to inoculation with Bradyrhizobium sp (Lupinus) combined with plant growth promoting Rhizobacteria (PGPR) under newly reclaimed soil condition. J. Agric. Sci. Mansoura Univ., 31 (7), 4613-4622.

Rana, M.C.; Datt, N. and Man-Singh (2006). Effect of Rhizobium culture in combination with organic and chemical fertilizers on rajmash (Phaseolus vulgaris) under dry temperate conditions of Himachal Pradesh. Indian Agric. Sci., 76: 151-153.

Ravindar, K. and Chandra, R. (2008). Influence of PGPR and PSB on Rhizobium leguminosarum Bv. Viciae strain competition and symbiotic performance in lentil. World Journal of Agricultural Sciences 4 (3): 297-301.

Sanoria ,C.L. and Yadav, J. (1993). Testing of strain of Rhizobium phaseoli on fresh bean (Phaseolus vulgaris) under greenhouse and field condition. Indian. J. Agron, 38: 28-32.

Semu, E.; Msumali, G.P. and Chowbery, M.S. (1982). Nodulation and yields of beans as affected by seed inoculation and nitrogen application. Soil Sci. Soc. East Africa., 56-65.

Shehata, S.A.; Rashad, H.M.; Taha, S.S. and ElSayed, S.S.F. (2007). Response of snap bean to two biofertilizers and different levels of nitrogen. J. Agric. Sci. Mansoura Univ., 32(8): 6259-6273.

Singer, S.M.; Ali, A.H. and El-Desuki, M.M. (2000). Synergistic effects of bio-and chemical fertilizers to improve quality and yield of snap bean grown in sandy soil. Acta Hort., 531: 213-220.

Singer, S.M., Shata S.M. and Azzazy M.A. (1996). Response of snap bean grown calcareous soil to some mineral nutrition and bio fertilizer treatments. Egypt. J. Appl. Sci., 11: 202-213.

Singh, C.S. and Subba Rao N.S. (1979). Associative of Azospirillum brasilense with Rhizobium japonicum on nodulation and yield of soybean. Plant and soil, 53: 387-392.

Snedecor, G.W. and Cochran, W.G. (1980). Statistical Methods. $7^{\text {th }}$, edition. Iowa State Univ. Press. Ames. Iowa.

Stewart, E. Allen (1989). Chemical analysis of ecological materials. Blackwell Scientific Publications. Oxford London Edinburgh p.p. 368.

Taussky, H.H. and Shorr, E. (1952). A microcolorimentric method for the determination of inorganic phosphorus, J. Biol. Chem., 202: 615-685.

Vincent, J.M. (1970). A Manual for the practical study of the root- nodule bacteria. IB p.15. Prentice Hall International, Ltd., New Jersey, USA.

Wollum, A.G. (1982). Cultural Methods for Soil Microorganisms. Pp. 781-802. In: Al-Page (ed). Agronomy series No.9. Methods for Soil Analysis, part 2. chemical and Microbiological Properties. Amer. Soc. Agron. Madison. Wisconoson, USA.

Yadava, U.L. (1986). A rapid and non-destructure method to determine chlorophyll in intact leaves. Hort. Sci., 21: 1449-1450. 


\title{
تأثير التلقيح بالريزوبيا والأزوتوياكتر والباسلس ميجاتيرم علي تكوين العقد الجذرية والمحصول والجودة لصنفين من
} الفاصوليا الخضراء

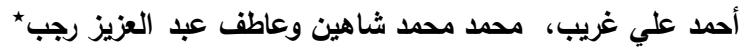 \\ قسم الخضر - كلية الزراعة - جامعة القاهرة

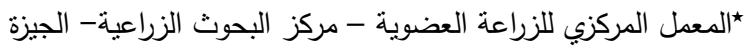 \\ الملخص العربي
}

أجري هذا البحث خلال موسمي الزراعة للأعواج2007، 2008 في محطة البحوث والتجارب الزراعية التابعة لكلية الزراعة - جامعة القاهرة

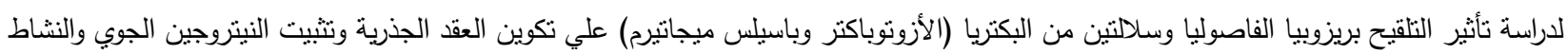

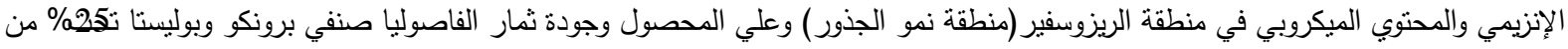

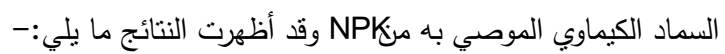

وجد أن معاملات التلقيح بخليط من السلالات أعطت ثأثيرا معنويا علي النمو وتكوين العقد الجذريه وتثبيت النيتروجين الجوي وكذللك

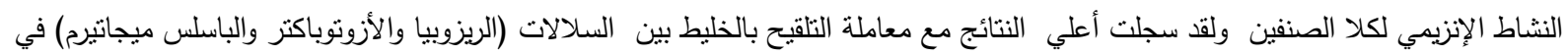
وجود 25\% من السماد الكيماوي NPK الموصي بهين. تفوق الصنف بوليستا علي الصنف برونكو بالنسبة لصفات ارتفاع النبات ، الوزن الطازج والجاف للنبات وكلاً من عدد الافرع وعدد

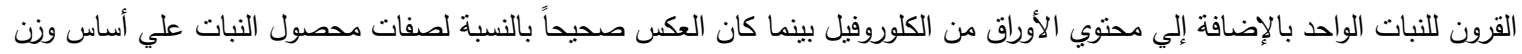
الثمار والمحصول الأخضر المبكر والكلي وكذلك المحصول الجاف للفدان، ووزن وقطر القرن بالإضافة إلي محتوي من الإفي

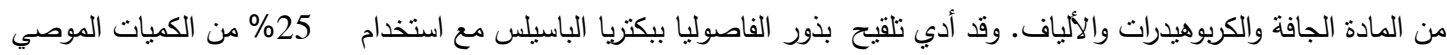
بها من السماد المعدني (NPK) إلي زيادة معنوية في جميع صفات النمو الخضري والمحصول ومكوناته ومواصفات القرون وذللك مقارنة بالكنترول

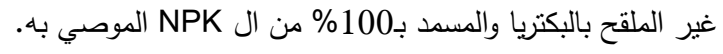
أظهرت معاملات التفاعل بين الأصناف و التلقيح بسلالات البكتريا أن المعاملة بالريزوبيا والباسلس و

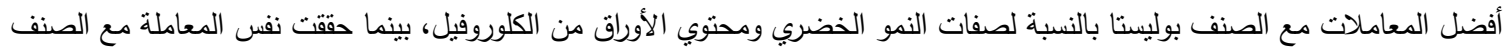
برونكو أفضل القيم بالنسبة لصفات المحصول ومكوناته بالإضافة إلي مواصفات جودة الثمار . 